\title{
Law and Politics in Nigeria: The Political Functioning of the Judiciary in Colonial Nigeria, $1940-1960$
}

\author{
Maurice Ayodele Coker \\ Department of Political Science, University of Calabar, Calabar, Nigeria \\ mauricecoker@unical.edu.ng; coker_maurice@yahoo.com
}

\section{Doi:10.5901/mjss.2014.v5n20p2084}

\begin{abstract}
The relationship between law and politics are sometimes taken for granted. In Nigeria during the period under study, law and particularly the courts largely underlie the arena in which politics were played. Indeed, legal decisions more or less were determined by political considerations than the legal interpretations and guidance. A survey of extant literature and documents on the subject was adopted to examine the relation of the organisation of the judiciary to the policy problems of political order and economic development. The study assumed and confirmed that the politics of establishing the sovereignty of a particular interest group resulted in: (i) the emergence of conflict between the British authority on the one hand and the Nigerian interest group on the other; (ii) the conflict between and within the Nigerian interest groups for the control of political power, by overthrowing the British political class necessitated the intervention of the Colonial Authorities; and, (iii) the assumption of political power by collaborating group brought into view two responsibilities, namely: (a) the replacement of the British political elites, using the inherited colonial institutions for the maintenance of political control; and, (b) the usage of the inherited colonial institutions to develop some sort of ESPIRIT DE CORP among the emergent comprador bourgeoisie.
\end{abstract}

Keywords: Political functioning, law, judiciary, courts, politics

\section{Introduction}

The study of law and politics has been of great interest to scholars primarily because of its impact on the body politics or the political system per se. Indeed, this interest could be traced to the early philosophers. For instance, an early philosopher, Aristotle in the Politics asserted the inevitability of the constitutions in the political life of a society. Also, scholars, such as Harrold Lasswell (1965), C. Herman Pritchett et al (1941), Kenneth Vines (1970), Walter Murphy (1966), and Glendon Schubert (1965) have contributed substantially to the study of the courts in politics (cited in Becker, 1970). These scholars went beyond the purely legalistic case study analysis and the legal structural descriptive methodology of the earlier scholars. This interest by the political scientist toward a more generally acceptable theory of judicial politics could be explained by the closely-knit nature of law and politics. This relationship has become very distinctive as the Judiciary is often regarded as the sine qua non of the political system due to the fact that, it seeks to mediate the process of "authoritative allocation of values in the society" (Easton, 1965). An aspect of the instrumentality of these decision-making is the judicial process; through the Structure of Courts (others being the legislative and executive processes). However, in the past, most scholars, especially the lawyers were not interested in the factors that underlined these laws, which came into existence. This assertion is clearly stated in Murphy and Pritchett in their book Courts, Judges and Politics, inter-alia:

The attention of most lawyers and scholars of the law has been primarily on the law produced, not on the process by which it was produced.... But political scientists have sought more and more to develop an approach to the judicial process which would give activities of the Courts new meaning by placing them within the mainstream of political relationship (1961, p vii).

These scholars sought within that framework to relate the functions of the judiciary to the concept of courts. However, such functions connotes so much that it turns out to describe very little. Specifically, the judicial function is really only part of the law enforcement functions. Another political scientist, Charles Beard in 1944, clearly suggested that the "judiciary may be regarded as an executive organ engaged in the interpretation, application and enforcement of laws" (Beard, 194). Austin Ranny (1958) maintained that the judicial function is the enforcement of the law through legal or court processes. Nevertheless, all of these scholars do maintain the utility of the Courts as the 'enforcer' of laws made. 
Therefore, the pertinent question to ask is what underlies these laws? Is there other phenomenon which would explain their utility?

In Nigeria, there are scholars who have been interested initially in the study of the Judiciary. But, like their Western counterpart works failed to explain the relationship between the law makers and the rest of the population. Scholars such as Elias (1954), Nwabuaeze (1964), Obilade (1979) etc have published books on the judicial process and more especially on the machinery of justice in Nigeria.

On making a cursory observation, it will be found that their works were purely historical and descriptive analytically; and, substantially traces the historical evolution of the Nigerian legal system and its constitutional development. Nonetheless, Awogu's (1984) work is of great interest to students of politics and law, since it not only describes the 1979 constitutional framework, but sought to explain the various political scenarios that led to the framing of that Constitution, as well as the various political conflicts that arose and the part played by the judiciary in handling and resolving the process. Despite all the efforts by these scholars, the major motive by the political scientist in his study of law and politics is, to clearly identify the factors that motivate the establishment of a legal system in any political unit.

\section{Study Setting}

The establishment of the British domination in the Nigerian territory necessitated the establishment of an authority which not only conform to the structure of the society, but also to their colonial status. Okafor (1981) states that the Crown system was established for the colony, while a protectorate structures were formalized into what came to known as Northern and Southern Nigeria. This authority relationship could be traced to activities of early European merchants, who traded in both slaves (human cargo) and primary goods, which resulted in the contact between the natives and the European traders. Initially, this trade was carried out on the Coast, but extended later into the hinterland. The trading activities were often pregnant with dangers, and due to the unequal pattern of trade between the natives and the European traders, the contract of these trade were often very precarious, and subject to dishonour. In 1849, the British Monarchy established a Consulate at the (Spanish territory of) Fernando Po for the Bight of Benin and the Bight of Biafra. This was in response to a request by the British traders for protection. The area under the superintendence of the Consul (the first consul appointed was John Beecroft) extended initially form Lagos in the west to Bimba in the Cameroun. However, in 1853, Lagos was made a separate Colony (Nwabueze, 1964: 106). The Consul-General for these territories was accountable to the British Foreign Office (Okonjo, 1974: 1).

Okonjo further asserted that it was the activities of Sir George Tubman Goldie, who has been interested in the trading having negotiated and signed treaties with the inhabitants of the territories, that made it possible for the British (who initially were less interested in these territories) to established at the Berlin Conference of $1884-1885$, that she was the effective occupying power in the areas adjoining the Niger and Benue Rivers to whom must be entrusted the duty of enacting regulations to secure free navigations to all nations in the international waterways.

In order for the British to safeguard and protect their interest (especially commercial), the necessity of establishing their sovereignty in these territories became very paramount. Hence, they introduced the English Common Laws and a system of Indirect Rule. What must be noted is that the British rather than abolished the native laws and customs, sought to 'modernised' and retained those aspects which according to them were found to be "good". In fact, the Indirect Rule system utilized the native traditional institutions particularly, the Native Authorities to hasten the imposition of colonial rule in Nigeria, first in the Northern Protectorate and, later into the South.

The present legal system in Nigeria has passed through a chequered history of little more than one hundred and fifty-one years of life; precisely from 1863 (Elias, 1954: 3). The political differentiation of early Colonial Nigeria into Colony and Protectorate meant differences in the legal basis of laws promulgated. In the Colonies, and the protectorate of South, the colonial laws came in the form of ordinances enacted by the Central Legislative Council in Lagos, while for the North, laws were promulgated by proclamation of Decrees by firstly, the Lieutenant-Governor of the Northern protectorate and much later by the Governor-General of the amalgamated Nigeria (Elias, 1954). Gradually, the sources of the Nigerian Laws included Local Laws and Customs, English Common Law based on the doctrine of Equity and Statutes of general application as well as Local Legislation and Interpretation based thereon Law Reports, Textbooks and Monographs on Nigerian Laws and Judicial Precedents.

Retrospectively, in 1914, Lord Lugard established the Northern Council whose function was essentially advisory and deliberative. No more detail would be given here about this body but suffice to say that it had thirty-six (36) members, six (6) of whom were Nigerians, nominated to represent different parts of the protectorate. Lugard found this council very imperative having foreseen the problems of administering such a vast area as Nigeria without formal institutions for ascertaining the views of the inhabitants of the territory and of the principal commercial business and financial interests 
operating therein, somehow these interests were neglected in the membership of this Council (Okonjo: 80).

In 1922, a Legislative council was established by Her Majesty's the Queen order-in-council as a result of the reforms initiated by Sir Hugh Clifford (as Governor) in 1921. This constitutional Framework for the first time ever, provided for an elective principle, a provision was made for an election into the Legislative Council, though on limited adult suffrage. Lagos had three seats while Calabar had only one. Thus, emerged the first political party in Nigeria; the Nigerian National Democratic Party (NNDP). This party was led by the most venerable, veteran journalist and politician, Herbert Heelas Macaulay, and later the Nigerian Youth Movement (NYM) in 1938 to contest elections into these offices. They also offered a stiff political opposition to the Colonial authorities, thus, leading to further constitutional advance.

By 1947, Nigeria had become regionalised, with the coming into force of the Richard's Constitution of 1946. Thus the foundation stone of the Nigerian Federation was laid. There were three Regions: North, East and West. It must be noted that, this constitutional arrangement also set the "Ball" of conflict rolling in Nigeria, principally because, of the imbalance in size of the Regions. Notably, the Northern Region was more populated and bigger in land mass than both the East and West. On the other hand, both the East and West were educational and socio-economically more advanced than the North, hence there arose a contradiction. This contradiction has had an indelible mark on the political process of Nigeria since Independence, as the emergent and subsequent ruling class has made and has been making incessant attempt at redressing these imbalance.

Furthermore, the political institutions of the North were shielded from the influence of both the missionaries and their Southern Counterparts by the British administration further compounded this problem. In fact, the consequence of this "divide the rule" policy of the British Administration tended to worsen the situations of the Northern Region, as independence was approaching.

The inadequacies of the earlier constitutional arrangement and the socio-psychological variables gave vent to a more systematic and rigorous negotiation by the nationalist leaders. The consequence of their rationalist activities was the negotiations leading to the enactments of both the 1951 Macpherson and the 1954 Littleton constitutions. The Littleton constitution had visualised that the Regions could eventually become self-governing in all matters within their legislative competence, as a transitional stages towards full self-government for Nigeria as a whole. Hence emanating from the constitutional conference which met in London in May and June 1957 under the chairmanship of the then Secretary of State, Lord Lennox-Boyd, both Eastern and Western Regions became self-governing on $8^{\text {th }}$ August 1957 while the Northern Region became self-governing in 1959. It must be noted that the constitutions under which selfgoverning was granted to them expressly prevented from taking any action which would interfere with the Federal Government's responsibility.

In 1959, there was a general election aimed at recruiting of political personnel for the 312 seats in the new House of Representatives. Shortly after its inaugural session in January 1960, the House of passed a motion, moved by the Prime Minister, requesting the United Kingdom Government to grant independence to Nigeria on $1^{\text {st }}$ October 1960. In 1963, Nigeria became a Federal Republic within the British Commonwealth of Nations, except the British Cameroons which was administered as a trust territory under the United Nations.

\section{Statement of Problem}

This study examines the relation of the organisation of the judiciary to the policy problems of political order and economic development of Nigeria. The political interest groups has found that, in investing in the enterprises of political sovereignty the two basic policy problems mentioned above becomes paramount. They found that political order establishes the supremacy of a class and thus of their class interested in class rule. Economic development provides what might be regarded as the raison d'etre of their interest in class rule., both in terms of the organisation of the economy hence the promotion of the objectives of class through the use of the economy. For instance, in the colonial Nigeria the British ruling class found that in order to sustain their economic interest, it became imperative for them to organise the economy politically, however, with marginal economic development. This they did through the institutionalisation of economic policy of political leadership of the British dominant class. To achieve that goal, it stood to reason that the problem of political order become paramount. We are interested in how British dominion on the Nigerian territories was introduced and sustained. This domination was to ensure the implementation of its economic policies which were largely a sublimation of their material interests. Accordingly, the conception of political interest in sovereignty implies a business of politics and political process. In both activities, law become of paramount concern. This especially the case since the establishment of sovereignty over a people, particularly by alien, produces a situation of powerful resentment and agitation on the one hand and of domination in another which leads to the enactment of a set of laws which transform and govern, or directs this relationship. The establishment of a legal system become inevitable. This brought into view firstly; conflict between 
the British Colonial authorities on the on the one hand, and the Nigerian interest groups (represented by the Nationalist leaders) on the other hand. The Nationalist leaders found as repressive, as well as the exploitative nature and relationship of the colonial laws, which they perceived as representing the interest of the British ruling class, hence, their agitations to protect the 'interest' of the colonial people. The agitations of the nationalist further created a fundamental problem for the regime; namely: how to defend the legitimacy of the political order and, the use of the judiciary to defend that Order.

At another level, there emerged gradually conflict of group ascendancy in the sovereignty among the Nigerian Interest groups. This implies the politics of representation aimed primarily at overthrowing the British political order. This was viewed initially as an illegal politics. Of course, this struggle among the indigenous people gave rise to emergence of various groups striving for political ascendancy in the country. The colonial authorities intervened in this politics to contain the 'perceived' rebellion of these nationalist groups. Again, colonial authorities became more interested in eliminating the most dangerous or revolutionary group in order to promote and sustain the ascendancy of a colonial - Nigerian collaborator leadership. The Courts system was used by the Nigerian interest groups to legitimise their political activities by exploiting the Western notion of 'fairness', 'justice', and 'equality'. The British colonial rule was portrayed as not only exploitative, oppressive, illegitimate but also wicked, denying the people the right to progressive development of the society. These provided the basis for enhanced revolutionary politics aimed at quickening the pace of decolonising Nigeria

The activities of the Nationalist produced positive results: it destabilised the organisation of and management of the colonial economic development; it accelerated the process of "negotiation" between the British Colonial Authorities and the Nigerian Nationalist leadership, and within the Nigerian nationalist leadership itself. Accordingly, by this negotiation, the legitimacy and constitutional transfer of power and the independent constitution were fashioned. The problem then became one of relation of politics to legitimating on one, and of the politics of legality on the other hand.

This problem, however, did not disappear with the attainment political independence, but rather transformed itself into colossal administrative, legal, economic socio-politic problem for Nigeria over the years. The desire of the emergent indigenous leadership to consolidate their tenuous political base led them to embark upon the discriminate use of state machinery, enactment of laws which tended to promote the interest of particular ruling fraction of the governing class. This resulted in fierce struggle for economic and political hegemony within the ruling class which resulted in the 30-month civil war in Nigeria between 1966 and ended on 15th January 1970. Again, another precipitating factor of the gruesome episode was the discriminate use of the judiciary for political reasons. Most cases became political issues rather legal ones and were so decided to the chagrin and consternation of most Nigerians.

After independence, the emergent ruling faction of the dominant class employed instruments and political process earlier adopted by the colonial rulers to maintain the status-quo having become aware of the precariousness of their material base and hence their hold on government. The ruling elites realized that in order to maintain some kind of stranglehold on the instrument of public control, there was the need to embark upon some socioeconomic and political development strategy supposedly in the 'interest of the people'. However, such strategies were to further strengthen the economic and political base of the ruling class. These were affected through the enactment of necessary laws and the manipulation of other instruments of state coercion by the ruling class.

\section{Law and Political Order}

The establishment of law and political order in the peripheral capitalist nation such as Nigeria was undertaken to create a stable political system conducive for exploration and exploitation of her enormous natural resources. The ruling class pursue this task within the orientation of dominant bourgeois economic philosophy; to take the most out the economy and give little to the economy in return. The economic policies pursued since independence have tended to largely strengthen their material base. These policies were inherently contradictory in nature and character to their promises to the people during their electioneering campaigns. This consequently prompts a high level of dissatisfaction among the vast masses of the people. Sequel to these feelings by the masses is the question of legitimising the oppressive economic and political relations. The Colonial Authorities in order to legitimize their hegemonic relations, they introduced the Indirect Rule System circumscribed by the English Common law in their colonial territories, of which Nigeria was one. Laws were made, and Courts were established to adjudicate these laws. Underlying the establishment of the courts or the judicial structure was the imperative to establish and sustain a stable political order that could ensure the enabling environment for colonial domination and exploitation. These relationships did not however, change at independence as might have been expected but only metamorphosed in to another form - dependent capitalism.

In this paper, the concept law refer to a rule of action or body of rules of human conduct, which involves an idea of 
obligation with consequent sanction if violated. Laws in Nigeria include customs as well as English Common laws. Equity and Statutes, Local Legislations, and interpretations based thereon Law Reports, Law textbooks and monographs and judicial precedents (Elias, 1954).

It is important to note that a law does not create or activate itself; there must be institutional frameworks that produces and reproduces it. This is variously referred to as the 'Grundnorm' (Esho, 1985). The highest authority that is saddled with the responsibility in any society to create laws is referred to as the Grundnorm. It is not expected to be subject to any other authority, that is, the Grundnorm must have no higher rule behind it. According to Keelson cited by Esho, it is the FON ET ORIGO. Understandably during the colonial times the Grundnorm was the imperial authority of the Queen of England, her Parliament and the British Privy Council. The whole idea of the concept implies that whatever is accepted as the Grundnorm anywhere or at any time must command a minimum of support and effectiveness. Esho argues:

\begin{abstract}
Provision for such minimum of support should be one, to be such meaningful that would PLACE people affected thereby under obligation to accept the laws of the land as opposed to a situation which makes people obliged VIET ARMIS to obey. While the latter stance could be forced on the society by any dictator, the former is a VOLUNTA an acceptance of a situation generally by the people who are convinced only by justness in the cause (1985: 8).
\end{abstract}

In Nigeria, during the colonial time the people obeyed the British laws not because it a just laws, as its source was not legitimate (as perceived by the early West African Nationalists), they obeyed the laws as a result of the colonial shackles.

The institution or structure which gives more validity to the norms or laws is the Courts, which is invested with the power of adjudication on disputes and interpretations of these laws. Scholars including Charles Beard opine that the judiciary function is really only part of the enforcement function. Beard (1944) observed that "... from another point of view the judiciary may be regarded as an executive organ engaged in the interpretation, application and enforcement of law". To Ranny (1958), the judicial function in the political sense has come to encompass the enforcement of law through legal or court processes, and ordinarily the Judiciary is a policy maker though this function is considered to be the spheres of the legislature and executive arms of government. Indeed, the Courts function as a policy maker has become increasing accepted by political scientists. Hence, the Courts formulate, enforce and interpretation public policies.

Hitchener and Harbold (1965) provide us with the more generally accepted definition of the concept of court. They described the "essential nature" of court as follows:

1. It "administers justice" (a functional type of relationship).

2. It is " the provision by the State of an impartial judge to decide a cause" (structural factor involving normative, formal expectation); and

3. Its judicial process is circumscribed by determinate standards that cause disputes to be resolved according to law... (Structural and functional).

Similarly, another political scientist, Herman Finer (1949: 114) asserted that the Courts of Justices have the following variables: (1) a man or body of men; (2) with power to decide a dispute; (3) before whom the parties or advocates or their surrogates present the facts of the dispute and cite existing, expressed, primary normative principles (in statutes, constitutions, rules, previous cases) that (4) are applied by that man or those men, (5) who BELIEVE that they should listen to the presentation of facts and apply such cited normative principles impartially, objectively, or with detachment (judicial role), and (6) that they may so decide, and (7) an independent body (Barker, 1979). Given the above prescription, it becomes an interesting enterprise to attempt a glimpse into the Nigeria judicial process with a view to assessing the extent of inconsistency with Barker's deposition.

\title{
5. Basic Assumptions
}

It is assumed that the politics of establishing the sovereignty of a particular interest group in Nigeria brings into view the following:

1. The emergence of conflict between the British colonial authority on the one hand and the Nigerian interest group on the other hand; this conflict implied a politics of change of political Order. By extension, it created a scenario in which the British Authority was forced into the politics of defending:

a. The legitimacy of their (colonial) political order

b. The use of laws, hence the judiciary to maintain and enhance that political order

c. To begin negotiation with emerging indigenous challenger to political power. 
2. The conflict between and within the Nigerian interest groups for the control of political power, by overthrowing the British political class necessitated the intervention of the Colonial Authorities in order to:

(a) Eliminate the most "dangerous" individuals or groups; and,

(b) Promote the assumption into political power of a colonial collaborator group to whom power would be handed over to.

3. The assumption of political power by collaborating group would bring into view two responsibilities:

(a) They could replace the British political elites, using the inherited colonial institutions for the same end: namely; the maintenance of political control.

(b) They could use the inherited colonial institutions for more ambitious goals; especially to develop some sort of ESPIRIT DE CORP among the emergent comprador bourgeoisie.

\section{Law and Politics in Nigeria, 1940 - 1966}

The amalgamation of Nigeria as provided by the 1914 proclamation did not result initially in the institutionalization of a common legislative council for the whole country. The North was administered initially through the proclamation of Decrees of the Lieutenant Governor, while the Southern Protectorate and Lagos Colony had in 1922, a Legislative Council which sat in Lagos (Okonjo, 1974). In fact, throughout the twenty-three years of the existence of this council, the Northern protectorate was strictly kept out of its sphere of influence, only to the extent of debating and voting on the annual supply did they relate.

By 1940, there were the following sources of law in Nigeria: local laws and customs, English laws - the doctrine of equity and statutes of general application; local legislation and interpretation based thereon; Law Reports and monographs on Nigerian law and judicial precedents (Elias, 1954). At the point that in point in time when the British legal order was being put in place in Nigerian territories, the British seemed to have acted with some wisdom by giving statutory recognition to our existent laws and customs (Esho, 1985). There were two types of legislation effective in Nigeria, viz: the imperial legislation enacted in Britain and made application in Nigeria such as the Regimental Debt Act of 1893, and the local legislation enacted in the form of Ordinances or Proclamations such as the ordinance of the Settlement of Lagos, 1962 - 74 and the Proclamation of the Protectorate of Southern Nigeria, 1900 - 1906; and, the proclamation of Protectorate of Northern Nigeria, 1900 - 1913 (Elias, 1954). Furthermore, the Regions were created and empowered to make laws for the peace and good governance of the respective regions.

The enactment of the "Laws of Federation of Nigeria and Lagos" could be traced to $1^{\text {st }}$ June, 1916; enacted by the Governor (Lord Frederick John Dealtry Lugard) of the Colony and Protectorate of Nigeria with the advice and consent of the Legislative Council. An amendment to it was made in 1958.

It must also be emphasized that the Nigerian criminal law, as a law derived from the common law in theory manifests to a substantial degree the principle of Nulla poena sine lege - that a man may be punished only in accordance with the law. We shall see how this principle was mutilated in Nigeria, how and why some laws were created to the advantage of certain persons, and, to the disadvantage of some others depending on their relative positions on the existential socioeconomic and political power matrices?

Examinations of selected cases under the following headings are pertinent at this juncture to enable the explication of the interface between law and politics in Nigeria during the colonial period.

\subsection{Treason}

It is one of the most serious criminal offences in the Code punishable with death. According to Okonkwo and Naish, "the gist of the offence is the levying of war against the state in order to intimidate or overawe the president or the Governor or a State. A person conspiring with any person either within or without Nigeria to levy war against the state is guilty of treason. It is important to note at this period that the there was no trial of the above offence.

\subsection{Sedition}

Sedition is probably the one offence which most seriously impinges on the freedom of expression of the citizen. The inherent problem is the boundary between individual freedom of expression and the security of the State (See Section 51 of the Criminal Code and Laws of Federation and Lagos, 1958).

There is a question that has been very fundamental to the existence of law of sedition in a democratic state or system, for quite obvious the reasons to this question is in the affirmative. Primarily, it is in the interest of any State or 
society that they should be peace, order and stability, and again, there is hardly any right which has not a corresponding duty. Added to this, is the belief in democracy that the best way and the proper time to show and effective resentment to such government are by means of the ballot box during an election (Fakyode, 1977).

But, it should be observed that "what the law of sedition seeks to achieve is to prevent an "unconstitutional" overthrow of government or breach of the peace through virulent and malignant attacks on government or a 'class'. According to Fakayode, "fair criticism of the form and measures of government is allowed but intemperate and immoderate language is abhorred by the law". At this period, examples of cases that arises from the sedition law are the Queen V. the African Press Ltd. V. the Queen (1952: West African Court of Appeal (WACA) 57) and James Ogidi V. Commissioner of Police (1960, 5 FSC 251, WNLR: 92-201).

With regards to the first cited case, it was maintained that, sedition, it is an offence to attack the members of the police force or of the legal department and to impute the motives that they are doing their work with partiality and are aiding and abetting lawlessness. In the African Press Limited V. the Queen, the seditious words of the article complained of appear in a portion of the judgment:

Now the article in question warns the public to beware of the Administrative Officer, it proceeds that "they are at the same time most potent and most cleverly disguised enemies of your struggles for freedom. They are, with a few exceptions, incompetent, narrow-minded, arrogant and contemptuous. In spite of ocular demonstrations to the contrary, they continue to imagine that you are not fit even for the bogus constitution that is now being offered you (WNLR 1: 1957).

It further posits that:

They are looking forward rather "feverishly to your failures in the future and they are ready not only to exploit such failures to perpetuate their petty dictatorship, but also to contribute to them by subtle devices ... (Western Nigeria Law Report, 1: 1957).

Furthermore, to accuse members of the police force and of the legal department of partiality in the administration of justice is held to be seditious.

In James Ogidi V. Commissioner of Police alleging that the Customary Courts in Warri Division were instruments of oppression of the people who are politically opposed to the party in power in the region. Part of the judgement delivered reads:

\begin{abstract}
... what we are concerned here is a publication which the appellant caused to appear in one newspaper, and for which he sought further publicity in another paper and over the wireless. It gives no particulars from which the persons to whose notice it might come could form their own opinions as the media of mass persuasions seem quite out of place in relation to it. In a series of categorical assertions it accuses the customary courts of a whole Division of being the creatures of a political party, of deliberately discriminating against the opponents of that party, and of denying them justice, so that citizens are not safe with the courts. It is difficult to conceive of anything better calculated to bring into hatred or contempt the administration of justice in Nigeria than such an attack... we consider that the conviction was amply justified on the fact of the case (1960, 5 Federal Supreme Court, 1960: 253-254).
\end{abstract}

At this juncture, we shall trace the development, activities and the ideological stance of the various factions of the dominant parties that emerged and partook in the political process of Nigeria. With the introduction of elective principle in 1923, the evolution of political parties had become pertinent. But what is political party? According to Edmund Burke, it is "a body of men united for promoting by their joint endeavours the national interest upon, some particular principle in which they are all agreed"(1770). Professor Moyibi Amoda has noted that the Burkean conception of the party assumes the existence of a national arena in which the national interest is known, but in which groups differs as to the means of achieving the end (1972). He went further to argue that, however, there arise conflicts about nature of political goals, and about the political means with which to achieve those goals, especially where the national interest is still in the process of definition, since the society is still in a flux. And, hence, political contests become one of defining the goals to be sought by the society. Thus, in the absence of moderation on the part of political parties, conflicts may become very problematic to the extent that one group's (Amoda, 1972). In the Nigerian context, there were two groups in contraposition with one another. These groups comprise of the British Colonial Authorities and the various factions of the nationalists. That is, by 1954, there had emerged three political parties dominating the three regional arrangements.

According to Amoda, the immediate goal of the Nigeria National Democratic Party (NNDP) (founded to contest the Lagos legislative Council seats) was to win the Lagos election as a means of not only protecting the economic and political interests of the native traders and producers of Nigeria, but also to press for Africanization of Civil Service, as 
well as to promote the development of Higher education and the introduction of compulsory education throughout the country. The other political group was the Nigerian Youth Movement founded in 1938. This party was one for which most of the Southern political leaders, who later played important role in Nigeria had worked together under one banner. But in 1941, the party was split because of the ill-fated Ikoli-Akinsanya incident. The major reason for this unfortunate episode hinges on the thorny issue of 'tribalism'. It was unfortunate in the sense that, henceforth, it was difficult for political leaders to work together without mistrust and suspicion. But, it must, however, be noted that there were other factors more important that the bogey-man of tribalism' that can be adduced for that event.

In 1944, a melange of over forty organization including political parties, tribal unions, trade unions, literary association, professional association, religious groups, social clubs, and women's organization met in Lagos to from the National Council of Nigeria and the Cameroons. Membership in this party was organizational. The original membership included tow trade union, two political parties, four literary societies, eight professional associations, eleven social clubs and on e hundred and one tribal unions.

The ultimate objective of the party was to disseminate ideas of representative democracy and parliamentary government by means of political education in order to secure the independence of United Nigeria within the commonwealth. Between 1944 and 1948, the N.C.N.C. as it was the only national party; it spoke for the entire nation and had the support of nationalization in all the provinces. In 1946-1947, it undertook a tour of the country to mobilize the people in opposition against the Richard's Constitution of 1946, hence heightening the struggle for leadership than ever. Later the internal struggle in the leadership of the party between the Yoruba elites, who until then had dominated the political scene, and the more militant, aggressive and articulate Ibo elites, who until the arrival of Azikiwe from the United States in 1937 had been on the periphery of Nigerian politics, rendered the delicate fabric of the National Movement into two. According to Amoda, "the struggle could be seen as a class struggle between the conservative, status conscious Yoruba elite and egalitarian and more dynamic Ibo elite" (1972). Hence, the N.C.N.C. in the course of history had to become predominantly Ibo. Interestingly, Amoda also observed that, between 1948 and 1951, "tribalism and regional nationalism became not only the most legitimate but the most effective mans for educated nationalists to secure power. In 1951, elections to the Legislative Assemblies in all the regions accelerated the drift towards sub-group nationalism and 'tribalism' (ethnicity). According to Coleman (1971), "Educated Nigerian who aspired to fill the new positions of power and status opened up to Nigerians by that constitution realized that their most secured base of support would be the people of their own group". The goal of the N.C. N.C. was the establishment of welfare stat. the ideology of N. C. N. C. since 1951 oscillated between support for a federated or a unitary Nigeria. Its leadership was certainly more nationalistic than the leadership of the other two rival parties, that is, the A. G. and the N. P. C. However, the inconsistency of a socialist ideology and the leadership mainly led by petty bourgeois led to tension within the party. This struggle was seen as one between the old bridge, which Dr. Opara - symbolized, and the young, ideological and more radical wing, once isolated in the articulate but politically ineffective Zikist National vanguard. According to Amoda, this issue motivated the National President, Azikiwe, to issue an apology for his affluence and his membership in the bourgeoisie.

The Action Group came into existence as in "Eureka" to the threats of the Ibo represented by the N.C.N.C. indeed, the Action Group (1951) an equivalent of the Ibo State Union. The basis of membership of the A.G. was to be on an individual basis without any social, religious, or class discrimination, but the founders of the party also intended to concentrate on the Yoruba section of the Western Region, essentially for the hopes of winning the election to be held under the new McPherson Constitution of 1951. Among the immediate goal of the A.G. were:

1. The immediate termination of British rule in every phase of our political life.

2. The education of all children of school age, and the general enlightened of all illiterate adults and illiterate children above school-going age.

3. The provision of health and general welfare for all our people.

4. The total abolition of want in our society by means of any economic policy which is both expedient and effective (Awolowo: 1961).

The Action Group, as was shown in its founding members drew its leadership from the male of the educated (33\%) the professions (9\%) and business (35\%) (Amoda, 1972) thus, the A.G. represented the interest of a rising class of businessmen, lawyers, doctors and educated, although its support laid with the working class. Furthermore, the A.G. use of the traditional ruler was purely a matter of expediency and tactical manoeuvre. The leaders of the party, in agitating for political concessions from the British, demanded reforms to limit the autocratic powers of the Chiefs (Amoda, 1972). This was as a result of A.G's. perception of the British use of the native rulers to maintain its regime, hence it was decided that, in order to weaken the legitimacy of the regime; it must fight on both fronts.

However, it must be emphasized that in all its activities that Egbe Omo Oduduwa, and later the Chiefs were solidly behind the A.G. In fact, according to Amoda (1972), "the success of the A.G.'s eleven year 'rule' (1951-1962) had shown 
the masses where effective power lay: the native authority system had been democratized, patronage and threats of deposition had made manifest that no natural ruler could oppose the government and reign (the Alafia of Oyo), when he clashed with the government, was deposed: the party possessed the crucial power of sanction of appointment and deposition of Chiefs" (Coleman, 1977). He went further to note that "In 1958, for instance, only one of the fifty-four members of the Western House of Chiefs was identified as supporting the N.C.N.C" (Amoda, 1972).

Worth nothing is the point that due to the natural struggle for power with rival group the Egbe became inevitably politicized. "The A. G. and the Egbe, the with former having the Chiefs as protectors, later supporting the leadership of the Chiefs", merged and mobilized the predominantly illiterate, traditional population consequently emerged as the political heir of the British and having the Chiefs to a political subordinate position, it had to build its own support at the grass-roots in order to establish its own legitimacy.

Further, the A. G. emerged as government resorted to the use of its power of patronage to secure the support of the elite. It had controlling power over the marketing boards, fiancé corporations, and the National Bank ensured the continuing support of the bourgeois class from which it emerged. The party also embarked upon welfare programmes in order to ensure the continued support of the masses. Thus, according to Amoda (1972), the control of the masses became hinges on the provision of social services, economic development and political stability.

The Northern people Congress emerged in 1948 as a result of the merger of two cultural Groups, the Bauchi General Improvement Union and the youth Social Circle of Sokoto, but at first, under the name of Jamivan Mutenen Arewa. At the onset, the traditional rulers were suspicious of the activities of this Political Parties, but its leaders were cautious reformers who had known that without the support of the native rulers they would be a failure. Hence they made a special effort to convince the rulers that they were only interested in helping the traditional authority stave off the Southern Political invasion. In return they asked for a measure of from within the native authority system

In fact, some radical elements, such as the articulate leader Aminu Kano called for a drastic curtailment of the power of the traditional rulers. He broke away from the N. P. C. to form the Northern Elements Progressive Union (N. E. P. U.) - a more dynamic political party. Towards ensuring success at the 1851 election, N. P. C. declares itself a party "Progressive" Political party having received the endorsement of the rulers. Its leadership was drawn largely from the ranks of higher officials in the native administration (emirate). N. P. C. since 1951 to 1961 had established its supremacy in the North to the extent of being seen as one-party Region. On the question of ideology it had none, except, perhaps, the maintenance of the dominance of the chiefs and administration (emirate). N. P. C. since 1951 to 1961 had established its supremacy in the North to the extent of being seen as one-party Region. On the question of ideology, it had none, except, perhaps, the maintenance of the dominance of the chiefs and administration elite. Its motto was ONE NORTH, ONE PEOPLE, IRRESPECTIVE OF RELIGION, RANK OR TRIBE, and the party determined to mobilize all the people behind it.

\subsection{Political Parties and Classes}

From the above survey of the three dominant political parties, which took their places in their respective region, we shall examine their interest as a class. The new class that was budding at this crucial period of Nigerian history composed of teachers, lawyers, businessmen, and doctors. They formed the influential political and economic elite by their domination of the native administration. This dominance extrapolated from the party's control of banks, the marketing boards, and the finance corporations through which patronag4es ensured the loyalty of the new class or else, withdrawing of contracts, loans and extension of credit tended to be highly political. In other words, as Richard Sklar pointed out, "Commercial patronage, including loans, marketing boards licensing and governments contracting is channelled through public agencies that are quasi-political in nature and conception. In all regions, these agencies serve the political interest of the government party only". Therefore, the "new class" desiring to maintain their position of dominance or those aspiring to the 'new class' has no alternative than resort to the use of politics as a medium of social mobility.

Elections and electoral campaign tended to be a risky business. The members of the "new class" regarded an election as a "do or die battle". They essentially believed that the stakes in an election was too high to the extent that loss of an election might lead to not only loss of office, but also to serious financial and perhaps social repercussions (Amoda, p.38). Political campaigns were fierce, dominant parties adopted every possible means to defeat rival parties. This practice of politics created a highly critical and unsafe environment for the various political actors. The Courts and Native Authority structure were use to eliminate political rivals, or at least put a potential rival out of circulation, until elections was concluded. For instance, Anifowose (1982) observed that

The native Authority and its agencies constituted the chief weapon o rule by the regional ruling party. The traditional structure of Northern society made it possible for N.P.C to rely for support principally on the village and Districts Heads (p. 92). 
Because of the opposition posed by the United Middle Belt Congress (U.M.B.C.) to the N.P.C., various instruments of coercion were employed by the various organs of the Northern region. This was also the case in other provinces of the Northern Regions. For instance, these instruments included among others, the extensive administrative, judicial and police powers of the Native Authorities. Anifowose notes that "the machinery of control was extensive" as it

... oftentimes permits for party activities were refused to the opposition parties in favour of the N.P.C. Again, there were other qualifications imposed for any grant of permits to the oppositions (Anifowose, 1982; 94).

Secondly, the Native Courts were used to intimidate the supporters of the United Middle Belt Congress (U.M.B.C.). In fact, the appointment, promotion, remuneration and dismissal of Courts presidents and members not only depended on the N. A., but also there exist absence of separation of executive and judicial powers at the clan level. The Clan Heads were automatically the Presidents of grade D Courts. They were empowered to imprison any individual for up to nine months and there was no right to appeal against their judgements. The Courts were used to victimize and imprison the opposition for a variety of reasons, much of which were trumped up or phoney charges. Consequently, the opposition parties and groups vehemently denounced the N.A., and pronounced them as instruments of oppression and injustice in the hand of the majority political parties; especially the NPC. Furthermore, many opposition supporters often ignored courts summonses which resulted in their conviction for contempt of court. In fact, desperate attempts were often made to imprison opposition supports on flimsiest pretext, especially during election periods (Anifowose, 1982). Anifowose notes that the situation resulted in the overcrowding of the Gboko Prison especially during the 1957 elections.

\section{Summary and Conclusion}

The paper focuses on the interface between politics and law in Nigeria from 1940 to 1960 . There is no gainsaying that during this period that the colonial law provided the major plank upon which politics was played. This study suggests that most legal decisions taken Nigeria during this period were more or less determined by political considerations than the legal interpretations and guidance. This study acknowledges the relation of the organisation of the judiciary to the policy problems of political order and economic development of Nigeria. It notes that the political interest groups have invested in the enterprises of political sovereignty for two basic policy problems; namely: First, they found that political order establishes the supremacy of a class and thus of their class interested in class rule; Second, Economic development provides what might be regarded as the raison d'etre of their interest in class rule, both in terms of the organisation of the economy hence the promotion of the objectives of class through the use of the economy. Consequently, in the colonial and immediate post-colonial Nigeria, the British and succeeding ruling classes found that in order to sustain their economic interest, it became imperative for them to organise the economy politically, however, with marginal economic development. This they did through the institutionalisation of economic policy of political leadership of the British dominant class. To achieve that goal, it stood to reason that the problem of political order become paramount.

The British domination was to ensure the implementation of its economic policies which were largely a sublimation of their material interests. Accordingly, the conception of political interest in sovereignty implies a business of politics and political process. In both activities, law become of paramount concern. This especially the case since the establishment of sovereignty over a people, particularly by alien, produces a situation of powerful resentment and agitation on the one hand and of domination in another which leads to the enactment of a set of laws which transform and govern, or directs this relationship. The establishment of a legal system become inevitable. This brought into view firstly, conflict between the British Colonial authorities on the on the one hand, and the Nigerian interest groups (represented by the Nationalist leaders) on the other hand. The Nationalist leaders found as repressive, as well as the exploitative nature and relationship of the colonial laws, which they perceived as representing the British ruling class, hence, their agitations to protect the 'interest' of the colonial people. The agitations of the nationalist further created a fundamental problem for the regime; namely: how to defend the legitimacy of the political order and, the use of the judiciary to defend that Order.

\section{References}

1960) 5 F.S.C. 251 ,

(1960) 5 FSC 251

(1960) W.N.L.R.

Adigwe, F. (1961). Essentials of Government, Oxford University Press, Ibadan.

Alavi , H. \& Shannin Theodore (Ed) (19820 Introduction to the Sociology of Developing Countries, . Macmillan Press Ltd, London.

Amoda, M. (1972). Background to the Conflict: A summary of Nigeria's Political History from 1914". In: Nigeria: Dilemma of Nationhood: African Analysis of Biafran Conflict; Joseph Okpaku ed. The Third Press, N.Y,

Anifowose, R. (1982). Violence and Politics in Nigeria: The Tiv and Yoruba Experience. Noks Publishing Co Ltd. Enugu 
Awogu, O, (1984) The Judiciary in the Second Republic of Nigeria, Pacific College press Ltd.

Awolowo, O, (1961) Awo - The Autobiography of Chief Obafemi Awolowo. Cambridge University Press

Beard, C. A. (1944). American Government and Politics, New York, MacMillan

Becker.T. L. (1970). Comparative Judicial Politics: Political Functioning of Courts, Chicago: Rand McNally.

Burke, E. (1770). Thoughts on the Causes of the Present Discontents (London; Dodsley, 1770), [4], 118pp., and Do. (Dublin: G. Faulkner 1770), 80

Coker, M.A. (2011) Legal and Policy Bases of Direct Foreign Investments in the Era of Indigenisation (Economic Nationalism) in Nigeria, 1975 - 1985. Retrieved from http://www.iiste.org/Journals/index.php/DCS/article/download/1755/1850 Assessed on 21 January, 2014

Coleman, J. S. (1994) Nationalism and Development in Africa, University of California Press

Easton, D. (1965). Framework of Political Analysis, Englewood Cliff: Prentice Hall

Elias, T. O. (1954) Groundwork of Nigerian Law. Rutledge and Keegan

Fakayode, E. O. (1971) The Nigerian Criminal Code Companion. Ethiope Publishing Corporation

Finer, H. (1949). The Theory and Practice of Modern Government. (Revised edition, New York Holt

Hitchner, D. G. and W. H. Harbold (1965) Modern Government: A Survey of Political Science. $2^{\text {nd }}$ Edition New York, Dodd Mead

Lasswell, H. (1936). Politics, Who gets What, When and How? New York, McGraw Hill.

Murphy, W. F. (1966). Courts as Small Groups, Havard Law Review.

Murphy,W.F, Pritchett, C. Herman, Lee Epstein, Jack Knight (1941). Courts, Judges and Politics. University of California, Santa Barbara Nwabueze, B. O. (1964). Constitutional Law of Nigerian Republic. London: Butterworth.

Obilade, A.O. (1979), Nigerian Legal System. London: Sweet \& Maxwell

Ogbuagu V. Police (1953) N.L.R 139 (1952) 14, W.A.C.A 57

Okafor, S. O. (1981). Indirect Rule: The Development of Central Legislature in Nigeria, Thomas Nelson. Nigeria Ltd. Ikeja Lagos

Okonjo, I. M. (1974) British Administration in Nigeria, 1900 -1950: A Nigeria View, Noks Publishers

Okonkwo, C.O. \& M. E. Naish (1980). Criminal law in Nigeria, $2^{\text {nd }}$ edition, Sweet \& Maxwell

R. V. African Press (1957) WNLR 1

Ranny, A. (1958), The Governing of Men: An introduction to Political Science. Holt.

Schubert, G.A. (1965). The Political Role of the Courts, New York: Scott Forresman.

Sklar, R. (1963) Nigeria Political Parties: Power in Emergent African Nation. African World Press, Inc \& The Red Sea Press, Inc

The Constitution of the Federal Republic of Nigeria 1979, Department of Information, Lagos

The Queen V. African Press Ltd (1957) WRN LR

Vines, K. N. (1970). The Politics of Federal Courts. Richard J. Richardson 